DOI: $10.2478 / \mathrm{rpp}-2018-0019$

PhD in Pedagogy, Adjunct, MARIOLA MIROWSKA Jan Dlugosz University in Czestochowa, Poland Address: 4/8 Waszyngton St., Czestochowa, 42-200, Poland E-mail: kafedra_unz_pvsh_2015@ukr.net

\title{
POTENTIAL WITHIN STUDENT SUPPORT FRAMEWORK IN EDUCATIONAL SPACE OF POLISH AND UKRAINIAN HIGHER EDUCATION INSTITUTIONS
}

\begin{abstract}
One of the aspects of the university institutional renewal should be to improve the organization of conditions for the support of the student life opportunities. Determination of the student's needs and expectations in diagnosing his resources, opportunities and environment (university / family / local environment) will facilitate the organization of services for the student. The existing services system is fragmented causing organizational chaos and disorientation of the recipient and does not take into account the individual characteristics of the student. The method of an individual case may be an alternative to operating system in its extended formula. Its conception is divided into two stages: the diagnosis of student's needs and expectations and the individual assistance plan in achieving educational goals through the personal resources development and a more or less inner circle at the university. It has been concluded that organization improvement of the higher education institution activity should take place particularly through creating conditions conducive to the development of student potential. The student (life) opportunities building should take into account the individual needs, expectations and resources of the student as well as the organizational capabilities of the university, the family and the local environment. The responsibility of the existing units of the university is to provide support and assistance to the student although they operate in accordance with their own rules, clearly defined tasks and competencies without creating an entire (holistic) system for supporting the student potential in the age of globalization. The proposed method of organizing the conditions at the university permitting us to identify and develop the student potential to meet their needs in the perspective of multidimensional existence may be an individualized approach to the student.
\end{abstract}

Keywords: student potential, education, management, higher education, university, individual case method.

\section{INTRODUCTION}

Higher education reform (particularly in Poland and Ukraine) creates new challenges whose prospects can be proved only in practice. The situation attracting attention to the possibility of developing a teacher's academic career in the terms of their didactic achievements is an important point in the context of discussion. What is that supposed to mean? The higher education development is mainly determined by scientific development of teachers for example the number of scientific publications in both countries. Currently this index is fixed by the score in Poland: the more scientific publications, the more points and the more financing into the structural unit they operate in. This practice is only beginning to be implemented in Ukraine. Nevertheless it should be 
noted that after the institutionalization of this index in Poland the quality of education has been determined by the number of points in the university instead of the quality of scientific researches that has become weird "points disease".

The academic career development (academic degrees) also depends mainly on scientific development (the more publications the better) among teachers. Universities often forget about the major beneficiary of the educational institution they provide services, about the student in such an atmosphere (of a constant impulse to writing publications). Meanwhile a great attention is paid to a good teacher who must be a scientist in the new legal norms of the so-called "Constitution for Science" (Konstytucja dla nauk, 2018) in Poland and provided the advance to the academic career obtaining the didactic indexes of the university within the educational process expects to have a financial reward. Doublespeak appears in the educational process: the student as its participant (a user, a customer, a quality estimator, etc.) becomes spotted through the subsidies "following them" rather than the most valuable asset of the university. This raises the question of revising the role of all participants in the educational process and attracting attention to the student as a beneficiary of education, in the interests of which all activities of the university should be deployed as a provider of educational services.

Against this background an important the issue is also designated to organizational culture of an educational institution (Przyborowska, 2009), determining the character of the customer and the education services user, focusing on the process and results of education for both students and teachers and combination of researching and teaching activities by the last-named one and a place of this process in general functioning of the university. The question now arises in which way the university can respond the inquiries of modern science development in transfer of this knowledge on a one-off basis and support the student life opportunities as the basis for his potential educational achievements. In the age of multicultural education the issue seems urgent combining its two components: the university's potential and the student's potential which relations are regulated in the everyday life of the person as well as the institution. Modern challenges raise the question to the effect that a student cannot be perceived in the time of global changes as the one obliged to "wrap their head around" the volume of world knowledge in a certain scientific sphere. It is long since an education does not serve end in itself but rather is aimed at acquiring specific competencies that disclose in the context of university culture and university life taking into account the student ability for own life. The vital and educational potential are two indexes of the student requiring the recognition and balance in the process of acquiring a certain educational level, which should be considered under the conditions of modern universities particularly of Poland and Ukraine.

\section{THE AIM OF THE STUDY}

The aim of this article was to determine the directions of maintaining the student potential in their educational self-identification and the role of the university in that process as a higher educational institution. We set following objectives: 1) to outline the field of definition of "potential" and its components in the context of student development and education; 2) to outline the possibilities of a higher education institution to develop and support the student potential in their life self-determination.

\section{THEORETICAL FRAMEWORK AND RESEARCH METHODS}

Student potential issues are studied primarily in the context of long-term development and resource availability for its provision in the field of applied researches: scholarly works are concerned in the process of student knowledge acquisition and the 
application of teaching methods that would actualize the student potential (M. Debych, N. Demianenko, N. Divinska, E. Dmitrieva, Yu. Hushchin, H. Onkovych, R. Novak (2017), B. Voronkova). The issue of maintaining the student life opportunities turns out to be insufficiently revealed in the terms of university study in order to strengthen their ability to acquire knowledge and obtain an appropriate educational level.

The research was carried out by the method of theoretical generalization and analysis of practice in this field.

\section{RESULTS}

The concept of potential (from Lat. Potential - power, strength, opportunities) indicates the presence of specific resources that possess the potential state and may occur under certain circumstances as well as conjunction of certain tools that may be brought into action under certain circumstances in the furtherance of this purpose. "Actualization of the potential" is reportedly a transition from a hidden state to a true, real one in the frame of this concept.

The concept of potential is the subject of research in various scientific fields in particular demography (L. Hersh, S. Pyrozhkov, E. Vielrose) where studying life opportunities indicates life expectancy of an individual and the impact of various factors on its dynamics appearing one among major demographic indexes (Pidhornyi, \& Vitkovska, 2008; Statystychni metody otsinky, 2015). The life potential is the basic concept and the general index of potential demography: the average life expectancy of a person points at their life potential (Pidhornyi, \& Vitkovska, 2008; Statystychni metody otsinky, 2015; Shevchuk, \& Shvydka, 2012). The problem of an individual life potential was studied in philosophy in the writings by I. Blauberg, A. Huseynov, E. Husserl, S. Ikonnikov, I. Kon, N. Marinets, N. Motroshylova, F. Nietzsche, A. Schopenhauer, L. Sohan, N. Smyrnov et al. These study relates to the meaning of human life, their background knowledge and "life breakthrough" (Marinets, 2010).

The category of life potential stands to gain personal characteristics in psychology and is studied as a personal potential, which also possesses a proper practical embodiment indicating the need for a person in personal growth (Rogers $\mathrm{C}$.) and the desire to behold the meaning of life (V. Frankl) (Hordieieva, \& Efimenko, 2013; Leontiev, 2011; Frankl, 1990). Such scholars as I. Bekh, S. Maksymenko, M. Sliusarevskyi, V. Rybalka, devoted their researches to study it. In general, the concept of life potential is studied from the perspective of three directions such as: medical and biological (A. Dubrovskyi, I. Schmalhausen, F. Selivanov), psychophysiological (P. Anokhin, N. Bernstein, A. Kohan, V. Nebylicyn, P. Simonov, B. Teplov) as well as sociological and socio-pedagogical (B. Ananiev, A. Bodalov, E. Erikson, V. Frankl, E. Fromm, I. Kon, A. Maslow, C. Rogers, B. Zeigarnick) (Prima, 2000). Medical and biological direction points at human health as a basis for the preservation and development of its potential. Regarding education all its technological processes should be focused on preserving the health of a pupil, a student and a teacher. The psychophysiological direction fixes the physical resources of a person, his abilities and capacities for a certain activity. Nevertheless the sociological and socio-pedagogical direction reveals human activity in the system of social influences governing its development. Therefore the learning environment of a student can be precisely represented by this group of factors at the university.

N. Marinets emphasizes two levels in the structure of the person's life potential: the basic (physical, mental and social health of a person) and activity one reflecting at different 
sciendo Порівняльна професійна педагогіка 8(2)/2018

Comparative Professional Pedagogy 8(2)/2018

levels of the human livelihood as physical, psychological, intellectual, social and cultural (Prima, 2000). However, the researchers do not have a common view on the structure of the individual life potential although its composition preferably consists of three components overall correlated with such concepts as "body-mind-soul" but may include others such as ethical, professional qualifying, psycho-social one, etc. (Marinets, 2010). Researchers explaining the life potential of the individual emphasize on its features as autonomy, inner freedom, vitality, conscious life, readiness for internal change, the ability to perceive new information, readiness for an active position and ability to plan activities (Marinets, 2010). The interdependence and complementarity of these characteristics will ensure the success of the individual in the life. Culture, education and self-education are admitted major factor in shaping the life potential of the individual in the scientific literature.

Individual potential is considered as the main one driving force of a public progress. An individual who has not formed (or lost) their own life potential becomes a passive product of circumstances "floating downstream". At the same time, an individual of high life potential is the active subject of history, own life, creativity and freedom. Therefore the life potential is a source of creativity and freedom. It is a way of selfprogramming and realizing own life by a personality and it functions at the stage mature personality. Such personality is characterized by a high level of self-awareness and culture, enlightenment, reasonableness. A person "trusts in own mind" and uses it in any situation. Mind efficiency directly and clearly depends on its tight interaction with feelings and will considering as components of the individual life potential. Self-realization of the life potential identifies the destiny of an individual. And if their destiny is realized the life of the last-named becomes art, beauty, kindness, pleasure.

The individual life potential is formed on the basis of severe effect and interaction of both internal and external factors such as the way of life and culture, family and production, social relations, education, education, etc. A special place among these factors is emphasized for the state with its inherent wide possibilities and levers of influence on a person. This institute assumes the responsibility for creating and maintaining a favorable social climate that is to say responsibility for favorable living conditions of an individual. Totalitarian countries as a rule destroy the individual life potential and democratic countries develop it (Marinets, 2010).

Hence we can say that the student life potential should be based on the basic level of his health support (mental, physical and social) during his studies at the university and the socio-pedagogical influences of the educational conditions should serve as opportunities for self-realization of a young person, its activity in the implementation of the ideas and thoughts learned in the process of education, serve the achievement of successful situations and a perspective vision of their own career growth. According to N. Marinets (2010), education as a specially organized process of mastering the general and professional social experience as well as the formation of individual experience on problem solving of pupils and students on this basis, enrichment of individual experience and the disclosure of their creative possibilities is a complex external factor of the individual life potential development. Education reform requires a re-examination of the student role at the university in preserving and developing their life potential as the grounds of education and self-development. So far the institutional renewal (particularly in school) is traced to three aspects (Błaszczyk, 2009):

1) individual development of teachers - personal development based on the need for continuing improvement of subject knowledge and didactic skills; 
2) methodological competences through the development and diversity of learning forms as well as the exposing of content beyond the defined program and new places of acquiring knowledge and skills;

3) organizational development - creating conditions for the potential development of students, teachers, administrative staff and consequently the entire organization.

The third dimension precisely indicates the improvement of the educational institution as a factor establishing the conditions for student potential development. The student potential is understood to mean all the vital resources of the physical, biological, social, mental and spiritual type the student possesses which could be used (or not used) by them in the life. Examples of resources are health, intelligence, talents (ex.gr. artistic, linguistic), perseverance, honesty, kindness, religiosity, stress tolerance, family relationships, acquaintances, roles, social positions. Whether it will be applied and to which extent depends on the activity of the person and the stimulation of the environment (external conditions).

A holistic approach to a person requires us to consider a student at the university as an integrated, multidimensional educational facility. The university studying should become "investment good" not just a "consumer good" (Potulicka, 2012). Only then will we realize the mission of the university which is to support the development of a person for their self-development and improve the quality of the university culture.

Systematic approach to learning provides a multidimensional student training for life in modern society and therefore it develops not merely academic but also other skills (training skills, responsible for their own learning, the ability to assess themselves and their progress, the ability to think critically, collaborate with others, entrepreneurship and skills to use advanced technologies, etc.). Taking into account the university task of improving the organization of an educational institution by creating conditions for the development of student potential, the question arises how to organize it?

Ability to support the student life potential identifying and developing the resources containing therein may be a method of an individual approach to a student (Mirowska, 2017). Reference to method of individual cases seems appropriate theoretical and practical foundations of which were introduced Mary Richmond. Based on polish social pedagogy the method of conducting the case was propagated and applied by Helena Radlinska. She took the work with the case to mean awakening, activating and directing the person to the system of auxiliary measures.

The influence of this method on the organization of an educational institution is possible through diagnosing the needs and resources (material, intellectual, social, emotional, spiritual and others) of the student and the facilities of environment (university/outside environment). In order the needs to be met and resources transform into life potential appropriate situations such as educational, social and cultural conditions should appear which will allow to release and strengthen it.

To achieve the diagnosis purpose we distinguish the conditions as the field of services provided to students by the university as well as the volume of their expectations and needs:

1) the sphere of services provided to students (educational, auxiliary, socio-cultural, etc.) within the legal framework (external and internal acts);

2) volume of student expectations and needs:

- in the educational field (educational services - educational programs/training for a profession (practice, internship, additional courses, consultations, participation in conferences, etc.); 
sciendo Порівняльна професійна педагогіка 8(2)/2018

Comparative Professional Pedagogy 8(2)/2018

- in terms of assistance and support offered by the university (assistance - financial accommodations (scholarships, grants, discounts, subsidies, etc.); non-financial: career guidance, psychological support, support for people with reduced capabilities, legal advice, etc.);

- in terms of participation in the social and cultural life of the university/and the further surrounding community (scientific circles, development of interests, participation and organization of cultural/sporting events at the university and beyond it, volunteering, etc.);

- in the field of student operating at the university (rights, responsibilities, availability of services, information about it, accessibility and training in higher educational institutions, self-government, meaning of influence and efficiency (introduction of democracy);

- expectations of students in the field of service management at the university (student affairs management using an individual approach).

Cognitive diagnosis as shown in the above-mentioned student needs and expectations ranges should focus on many aspects of student life using their resources and the system of delivery services not just educational which function in the university space. It is interesting to show not only the official (institutional) places of student support but also to systematic organization of these places in the university space depending on the student expectations, the organizational capacity of the university and the independent functioning of the student in society and in the labor market.

\section{CONCLUSIONS}

Organization improvement of the higher education institution activity should take place particularly through creating conditions conducive to the development of student potential. The student (life) opportunities building should take into account the individual needs, expectations and resources of the student as well as the organizational capabilities of the university, the family and the local environment.

Introduction of the student to labor market is the main function the higher educational institutions focus on which means fragmentation of education. Currently the provision of services at the university mainly aimed at providing knowledge, getting abilities is secondary and the last one is the competence of the student. Conditions to be created for the development of student potential are often neglected or organized not properly in the university space.

The responsibility of the existing units of the university is to provide support and assistance to the student although they operate in accordance with their own rules, clearly defined tasks and competencies without creating an entire (holistic) system for supporting the student potential in the age of globalization. The proposed method of organizing the conditions at the university permitting us to identify and develop the student potential to meet their needs in the perspective of multidimensional existence may be an individualized approach to the student.

\section{REFERENCES}

1. Błaszczyk, K. (2009). Szkoła wobec międzynarodowych tendencji edukacyjnych w perspektywie zarządzania. In K. Błaszczyk, M. Drzewowski, \& W. Maliszewski (Eds.), Komunikacja społeczna a zarządzanie we współczesnej szkole (pp. 16-27). Toruń: Adam Marszałek.

2. Frankl, V. (1990). Chelovek v poiskah smysla. Moskva: Progress.

3. Hordieieva, A. V., \& Efimenko, A. P. (2013). Osoblyvosti sensu zhyttia ta osobistisnoho potentsialu pidlitkiv, pozbavlenykh batkivskoho pikluvannia. Problemy suchasnoii psykholohii, 21, 69-79. 
4. Konstytucja dla nauki. (2018). Pobierz projekt „Konstytucja dla nauki”. Retrieved from http://konstytucjadlanauki.gov.pl/pobierz-projekt.

5. Leontiev, D. A. (2011). Lichnostnyi potentsial: struktura i diagnostika. Moskva: Smysl.

6. Marinets, N. V. (2010). Zhyttievyi potentsial osobistosti: formuvannya ta realizatsiya $u$ transformatsIynomu suspilstvi. (Avtoref. dis. kand. filosof. nauk). Natsionalnyi pedahohichnyi universytet imeni M. P. Drahomanova, Kyiv.

7. Mirowska, M. (2017). Case management (zarządzanie przypadkiem) jako technologia przyszłości w szkole wyższej. Pedahohichni nauky: teoriia, istoriia, innovatsiini tekhnolohii, 6 (70), 108-116.

8. Novak, R. S. (2017). Rozvytok osobistisnogo potentsialu studenta v protsesi navchannya za Interaktivnoiu modelliu. Molodyi vchenyi, 5.1 (45.1), 77-79.

9. Pidhornyi, A. Z., \& Vitkovska, K. V. (2008). Deiaki metodolohichni aspekty otsinky zhyttievoho potentsialu naselennia na rehionalnomu rivni. Visnyk sotsialnoekonomichnykh doslidzhen, 30, 308-314.

10. Potulicka, E. (2012). Uniwersytet na wolnym rynku. In E. Potulicka, \& J. Rutkowiak (Eds.), Neoliberalne uwiktania edukacji (pp. 281-297). Kraków: Impuls.

11. Prima, E. V. (2000). Zhiznenniy potentsial cheloveka kak bazovaya tsennost kultury. (Diss. kand. kulturologii). Nizhnegorodskiy gosudarstvennyi arhitekturnostroitelnyi universitet, Nizhniy Novgorod.

12. Przyborowska, B. (2009). Kultura organizacji w procesie zarządzania edukacją. In K. Błaszczyk, M. Drzewowski, \& W. Maliszewski (Eds.), Komunikacja społeczna a zarządzanie we współczesnej szkole (pp. 9-15). Toruń: Adam Marszałek.

13. Przywojska, J. (2014). Nowe zarzadzanie i governance w pracy socjalnej. Warszawa: CRZL.

14. Shevchuk, P., \& Shvydka, H. (2012). Formuvannya ta perspektyvy dinamiki zhittievogo potentsialu na period trudovoii diyalnosti. Ukraina: aspekty pratsi, 3, 38-44.

15. Statystychni metody otsinky sotsialno-ekonomichnogo rozvytku kraiiny $i$ regioniv. Mizhnarodna naukovo-praktychna konferentsiia "Naukovi problemy hospodariuvannia na makro-, mezo- ta mikro-rivniah". (2015). Odesa: ONEU. 